52 Lawrence D, Jablensky AV, Holman CD, Pinder TJ. Mortality in Western Australian psychiatric patients. Soc Psychiatry Psychiatr Epidemiol 2000; 35: $341-7$

53 Lawrence DM, Holman CDJ, Jablensky AV, Hobbs MST. Death rate from ischaemic heart disease in Western Australian psychiatric patients 1980-1998. Br J Psychiatry 2003; 182: 31-6.

54 Office for National Statistics. Adult Dental Health Survey. Oral Health in the United Kingdom 1998: 1-12. TSO (The Stationery Office), 2000.

55 Tsakos G, Herrick K, Sheiham A, Watt RG. Edentulism and fruit and vegetable intake in low-income adults. J Dent Res 2010; 89: 462-7.

56 Krutchkoff DJ, Eisenberg E, O'Brien JE, Ponzillo JJ. Cocaine-induced dental erosions. N Engl J Med 1990; 322: 408.

57 Sjogren R, Nordstrom G. Oral health status of psychiatric patients. J Clin Nurs 2000; 9: 632-8.

58 Sreebny LM, Schwartz SS. A reference guide to drugs and dry mouth 2nd edition. Gerodontology 1997; 14: 33-47.
59 Thomson WM, Lawrence HP, Broadbent JM, Poulton R. The impact of xerostomia on oral-health-related quality of life among younger adults. Health Qual Life Outcomes 2006; 4: 86.

60 Barnes GP, Allen EH, Parker WA, Lyon TC, Armentrout W, Cole JS. Dental treatment needs among hospitalized adult mental patients. Spec Care Dentist 1988; 8: 173-7.

61 Australian Research Centre for Population Oral Health, The University of Adelaide. Oral Health Promotion Clearinghouse (https:// www.adelaide.edu.au/oral-health-promotion/).

62 Almomani $\mathrm{F}$, Brown $\mathrm{C}$, Williams KB. The effect of an oral health promotion program for people with psychiatric disabilities. Psychiatr Rehabil J 2006; 29 274-81.

63 General Practice Queensland. Activate: Mind and Body. General Practice Queensland, 2009 (http://www.gpqld.com.au/page/Programs/Mental_Health/ Improving_the_Physical_Health_of_People_with_a_Severe_Mental_Illness_ Project/).

\title{
4:48 Psychosis
}

\section{Sarah Kane}

A room of expressionless faces staring blankly at my pain, so devoid of meaning there must be evil intent.

Dr This and Dr That and Dr Whatsit who's just passing and thought he'd pop in to take the piss as well. Burning in a hot tunnel of dismay, my humiliation complete as I shake without reason and stumble over words and have nothing to say about my 'illness' which anyway amounts only to knowing that there's no point in anything because I'm going to die. And I am deadlocked by that smooth psychiatric voice of reason which tells me there is an objective reality in which my body and mind are one. But I am not here and never have been. Dr This writes it down and Dr That attempts a sympathetic murmur. Watching me, judging me, smelling the crippling failure oozing from my skin, my desperation clawing and all-consuming panic drenching me as I gape in horror at the world and wonder why everyone is smiling and looking at me with secret knowledge of my aching shame.

Shame shame shame.

Drown in your fucking shame.

Inscrutable doctors, sensible doctors, way-out doctors, doctors you'd think were fucking patients if you weren't shown proof otherwise, ask the same questions, put words in my mouth, offer chemical cures for congenital anguish and cover each other's arses until I want to scream for you, the only doctor who ever touched me voluntarily, who looked me in the eye, who laughed at my gallows humour spoken in the voice from the newly-dug grave, who took the piss when I shaved my head, who lied and said it was nice to see me. Who lied. And said it was nice to see me.

4:48 Psychosis (p. 209), Methuen Publishing, 2001. We published another excerpt from Psychosis in the August 2011 issue of the Journal.

Chosen by Femi Oyebode. 